\title{
X-RAY FLUORESCENCE AND STABLE ISOTOPES ANALYSES OF IKPESHI MARBLE, SOUTH
}

\section{SOUTHERN NIGERIA}

Ikhane, Phillips Reuben; 'Oyebolu, Olalekan Olayiwola and ${ }^{1}$ Alaka, Afolabi Omotayo. Department of Earth Sciences, Olabisi Onabanjo University, Ago - Iwoye

Correspondence author E-mail: Ikhane.phillips@oouagoiwoye.edu.ng

\section{ABSTRACT}

Integration of X-ray fluor escence and stable isotope spectrometric techniques for quality assessment and provenance study of exposed marble deposit at Fakunle Quarry, Ikpeshi, South Western Nigeria constitute the fundamental aims of this research. Fourteen fresh (14) marble samples obtained at different localities within the quarry were subjected to geochemical and isotopic analyses to ascertain the quantitative abundance of major oxides and stable isotopes using X-Ray Fluorescence and Thermo Fisher mass spectrometer respectively. The major oxides revealed by XRF analysis of the

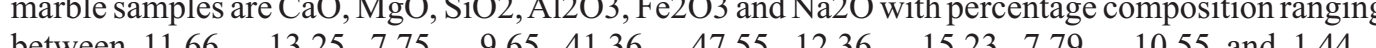
between $11.66-13.25,7.15-9.65,41.36-47.55,12.36-15.23,7.79-10.55$ and 1.44 relation to percentage of calcite-dolomite indicate a percentage range of -5 to $4 \%$ and $93-103 \%$ for Calcite and Dolomite respectively Chemical Index of Alteration (CIA) ranges from 45.16 to $51.59 \%$ and Chemical Index of Weathering (CIW) ranges from 46.19 to $52.30 \%$. Stable isotope ( $\square-180$ ) of marble ranges from -10.50 to -7.00 with a corresponding value from 25.50 to 55.33 .Interpretation of the overall results indicates an impure quartz-rich dolomitic marble; metamorphosed from a low carbonate sedimentary/meta sedimentary protolith which shallowly precipitated within a passive marginal marine environment under humid condition. The high silica impurity can however be attributed to the inordinate influx of terrigenous sediments during the precipitation process. between the obtained geochemical result and the basement geology of the study area.

Keywords: Marble, Meta sedimentary, Stable Isotope, dolomitic, mass spectrometer

Accepted Date: 12 June 2020

\section{INTRODUCTION}

Marble is one of the industrial rocks presently gaining prominence in the manufacturing sector of the Nigerian economy (Alabi et al.,2013) because of its wide range of industrial and domestic applications. Scott and Durham (1984) identified about 204 end uses of raw marble and lime (the calcined form of marble).The industrial use of a marble body is largely determined by its composition, required specification, end product and tonnage of deposit. Broadly, however, the economic values of marble can be classified under six main groups namely, metallurgical, chemical, environmental, construction, refractory and agriculture (Boynton, 1979). Each of these groups requires some chemical specifications for the marble to be useful. The research is aimed at determining the composition and provenance of the marble deposit at lkpeshi, Southwestern Nigeria using X-ray fluorescence and stable isotope analytical techniques.
LOCATIONAND ACCESSIBILITY

The study area is geographically located between longitude $6^{\circ} 5^{1} 24^{11} \mathrm{E}$ to $6^{\circ} 7^{1} 12^{11} \mathrm{E}$ and latitude $7^{\circ} 13^{1} 48^{11} \mathrm{~N}$ to $7^{\circ} 16^{1} 48^{11} \mathrm{~N}$, Southwestern Nigeria (Fig. 1a)and highly accessible through a network of inter connected footpaths, major and minor roads. Although area is plagued with a rugged topography the availability of favourable derived savannah
outcrops. 


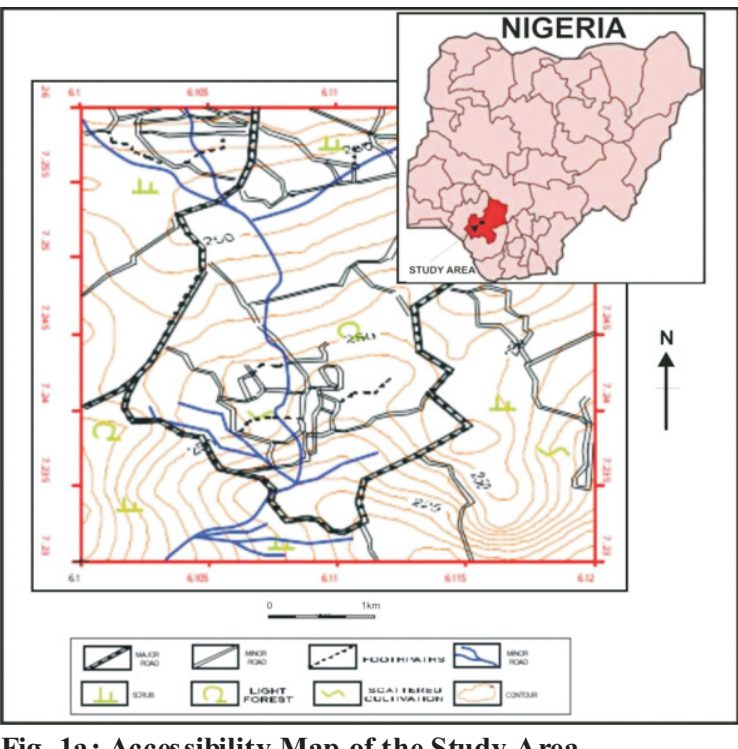

Fig. 1a: Accessibility Map of the Study Area



Fig. 1b: Geological sketchMap of Africa indicating Nigeria within reactivated Pan-Africandomain (Modified after Rahaman and Ocan, 1988)

\section{LOCALGEOLOGY}

The study area constitute part of the Nigerian basement complex and schist belt in particular lying east in a mobile belt of the West African Craton affected by the Pan-African thermo tectonic events (Fig.1b). Lithologically, the study area can be divided into three major rock groups which include dolomitic marble, quartzite, gneisses with metasedimentary cover.

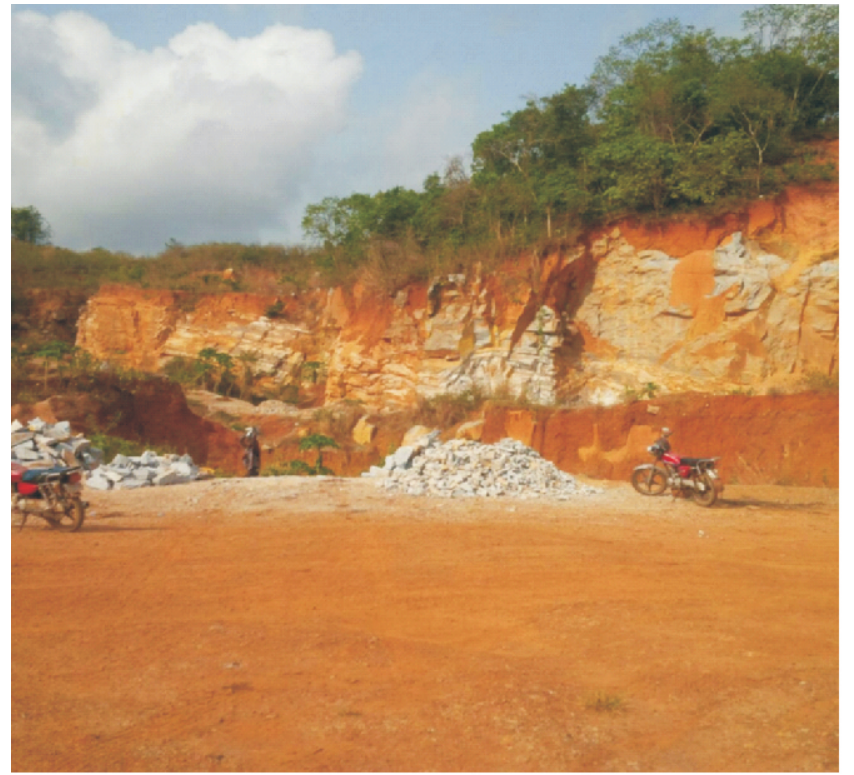

Fig. 2: Outcrop section in Fakunle Quarry site, Ikpeshi

MATERIALS AND METHODS

Fourteen spatially distributed marble samples within the confines of the quarry (Fig.2) were collected for analyses. Sequel to field activities, the marbles samples were prepared on a silicon carbide disc and ultrasonically

( $\mathrm{j}_{\mathrm{SN}}$ P-ISSN 2536-6904, E-ISSN 2705-2761 purified with methanol for 10 minutes and dried at $110^{\circ} \mathrm{C}$ for at least 2hours. Larger fragments were reduced to a diameter of $1 \mathrm{~cm}$ in a Spex shatter box, and furthe pulverized and transferred into the representative sample bags. Borate glass discs were then prepared for the X-ray analysis by mixing $2 \mathrm{~g}$ of ignited sample powder with $4 \mathrm{~g}$ crucible, the mixture was melted together in an inductio glass dise on which the whole rock analyses were made settings were at count of 800-1000 for standards and 100seconds for major elements/oxides

Analysis of stable isotope composition for carbon and oxygen was done by using a Thermo Fisher DELTA V mas Bench II and a CTC Combi-Pal auto sampler. For the decomposition of the fine-grained samples (approximately $0.2 \mathrm{mg}), \mathrm{H}_{3} \mathrm{PO}_{4}$ concentration was used in a 'He-flushed' dolomites); long-term precision turned out to be $0.06 \% 0$ for oxygen, and $0.05 \%$ for carbon, respectively.

\section{RESULT AND DISCUSSION}

The result of the X-Ray Flou rescence (XRF) and stable isotope analyses conducted on the fourteen marbles samples is depicted in Figure 3 and 4 respectively. I by XRF are $\mathrm{SiO}_{2}, \mathrm{Al}_{2} \mathrm{O}_{3}, \mathrm{CaO}, \mathrm{Fe}_{2} \mathrm{O}_{3}, \mathrm{MgO}$, and $\mathrm{Na}_{2} \mathrm{O}$, with a percentage composition range of $41.36-47.55,12.36$ $15.23,11.66-13.25,7.79-10.55,7.75-9.65$, and 1.44 1.75respectively (Fig. 3). Other compounds (oxides) presents include $\mathrm{P}_{2} \mathrm{O}_{5,} \mathrm{~K}_{2} \mathrm{O}$ and $\mathrm{TiO}_{2}$. Also stable isotope $(\delta-180)$ of the marble -10.50 to -7.00 (Fig. 4 ) lithe oven for several into a disc mould, and allowed to consolined was using an X-Ray Fluorescence spectrometer - connected online to a Thermo Fisher Gas atmosphere heated to a temperature of $700^{\circ} \mathrm{C}\left(900^{\circ} \mathrm{C}\right.$ fo descending order of abundance, the major oxides revealed

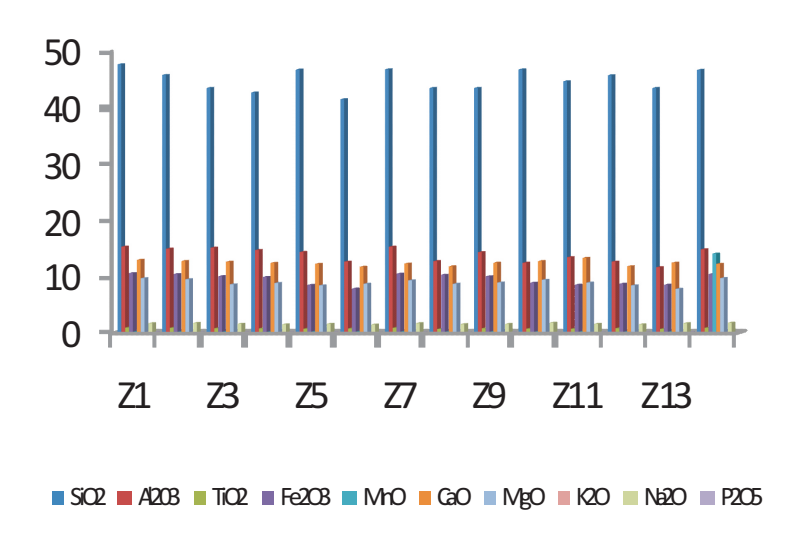

Fig. 3: Result of XRF Analysis of Ikpeshi Marbles

In consonance with the classification scheme of $7.75 \%$ for $\mathrm{CaO}$ a al., 1955 , a mean value of $12.35 \%$ and impure low-grade substandard dolomitic marbles. $\mathrm{CaO} / \mathrm{MgO}$ of Ikpeshi marble ranges from $1.26-1.60$, with seven out of the sample falling below the theoretical limit of 1.39 proposed by Grant, et al., 1989. The average content of silica $\left(\mathrm{SiO}_{2}\right)$ in the samples is $44.8 \%$; which can be closely connected to the periodical influx of near shore



Fig. 5: Total Alkalis Concentration in the Marble Sample

$\mathrm{Al}_{2} \mathrm{O}_{3}$ and $\mathrm{Fe}_{2} \mathrm{O}_{3}$ occur substantially in the marble samples confirming its enrichment in aluminosilicates (clay minerals). Figures 6 and 7 compares the chemical composition of sampled marble with typical calcitic and dolomitic marbles in other environments respectively. 


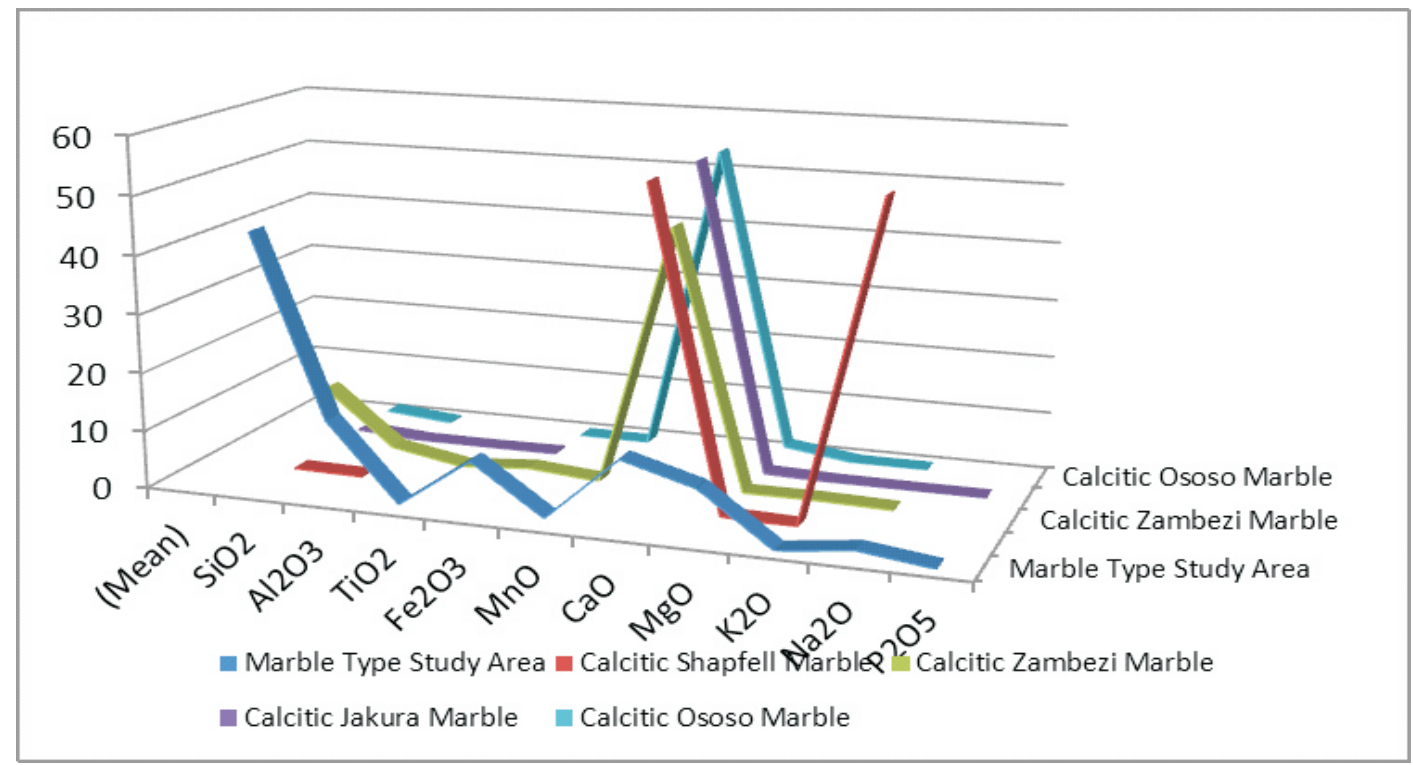

Fig.6: Comparison of Ikpeshi Marbles with Known Calcitic Marbles



Fig.7: Comparison of Ikpeshi Marbles with Known Dolomitic Marbles

\section{Marble Classification}

The $\mathrm{CaO} / \mathrm{MgO}$ ratio in the study area ranges between 1.26 and 1.60 , averaging a value of 1.40 . The relative percentage occurrence of calcite and dolomite in the investigated marble ranges between $-5 \%$ and $4 \% ; 93 \%$ and 103\% respectively; which apparently indicate a dolomitic marble type (Gold Schmidt et al., 1955).

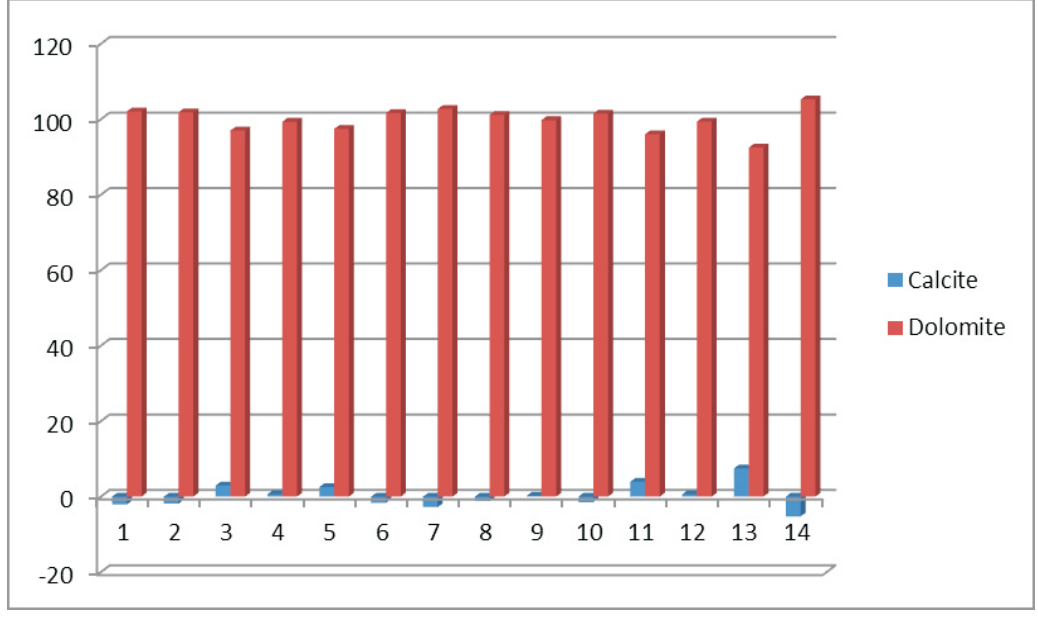

Fig. 8: Relative percentage composition of Calcite and Dolomite in the acquired samples

The ternary diagram classification scheme by Carr and Rooney (1983) for selected major oxides (CaO-MgO-SiO2) in the marble samples showed that marble sample from the study area falls within the calc-silicate group (Fig. 9a); none of the



Fig.9a: CaO-MgO-SiO ${ }_{2}$ Ternary Diagram Classification by (Carr \& Rooney, 1983)

A JSN P-ISSN 2536-6904, E-ISSN 2705-2761 African Journal of Science \& Nature Vol. 10, 102-113 (2020) 


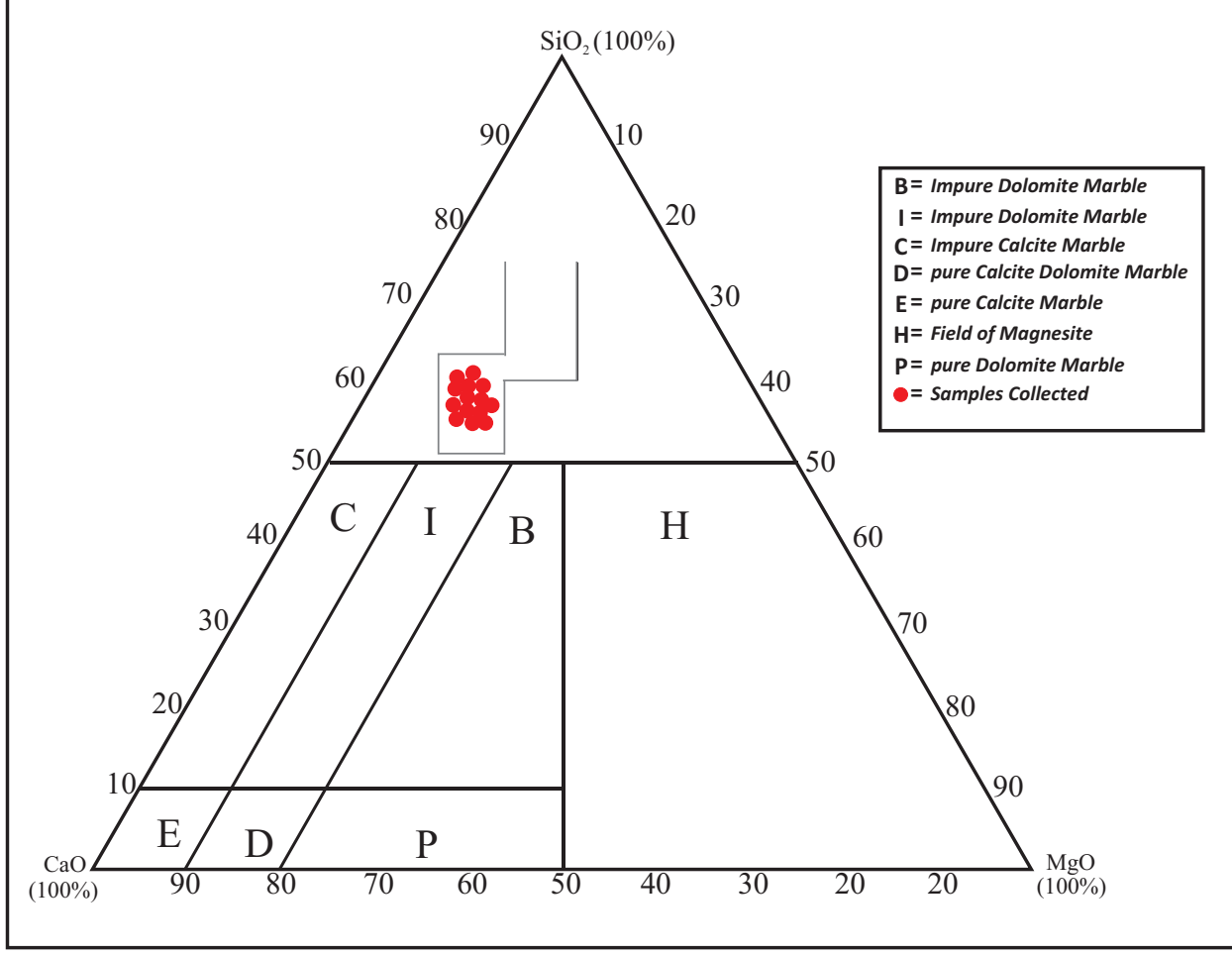

Fig.9b: $\mathrm{CaO}-\mathrm{MgO}_{\mathrm{SiO}}{ }_{2}$ Ternary Diagram Classification by (Storey and Vos, 1988)

Characterization of quartz content in the marble samples using the bivariate plot of $\mathrm{Na}_{2} \mathrm{O}$ versus $\mathrm{K}_{2} \mathrm{O}$, and $\mathrm{CaO}$ versus $\mathrm{MgO}$ (after Crook, 1974) indicate a contradictory quartz poor and quartz rich marble disparately (Fig. 10 and 11).



Fig 10: Quartz Content Bivariate Plot of $\mathrm{Na}_{2} \mathrm{O}$ vers us $\mathrm{K}_{2} \mathrm{O}$

A

P-ISSN 2536-6904, E-ISSN 2705-2761 African Journal of Science \& Nature Vol. 10, 102-113 (2020)

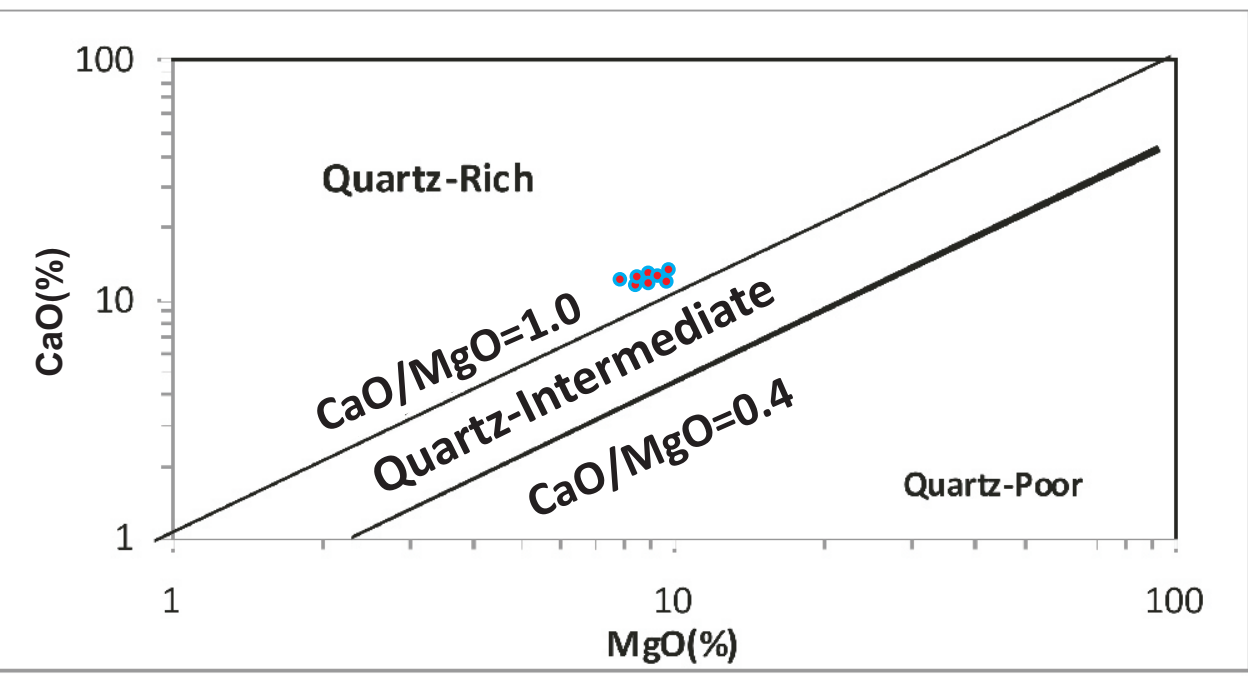

Fig 11: Quartz Content Bivariate Plot of CaOversus MgO

A discriminant plot of $\mathrm{Na}_{2} \mathrm{O} / \mathrm{Al}_{2} \mathrm{O}$, vs. $\mathrm{K}_{2} \mathrm{O} / \mathrm{Al}_{2} \mathrm{O}_{3}$ ratio of the examined marbles (Fig. 12) suggests aprotolith of metasedimentary origin, which strongly correlates with the field observations (marble crystallinity, deformed bedding planes, specks of dotted dark colouration of burnt organic matter)



Fig 12: Nature of Protolith $\left(\mathrm{Na}_{2} \mathrm{O} / \mathrm{Al}_{2} \mathrm{O}_{3}\right.$ vs. $\left.\mathrm{K}_{2} \mathrm{O} / \mathrm{Al}_{2} \mathrm{O}_{3}\right)$

A bivariate tectonic discrimination plot of $\mathrm{K}_{2} \mathrm{O} / \mathrm{Na}_{2} \mathrm{O}$ against $\mathrm{SiO}_{2}$ (after Roser and Korsch, 1986)specified the formation of marble protolith along a passive continental margin, away from the plate boundaries.

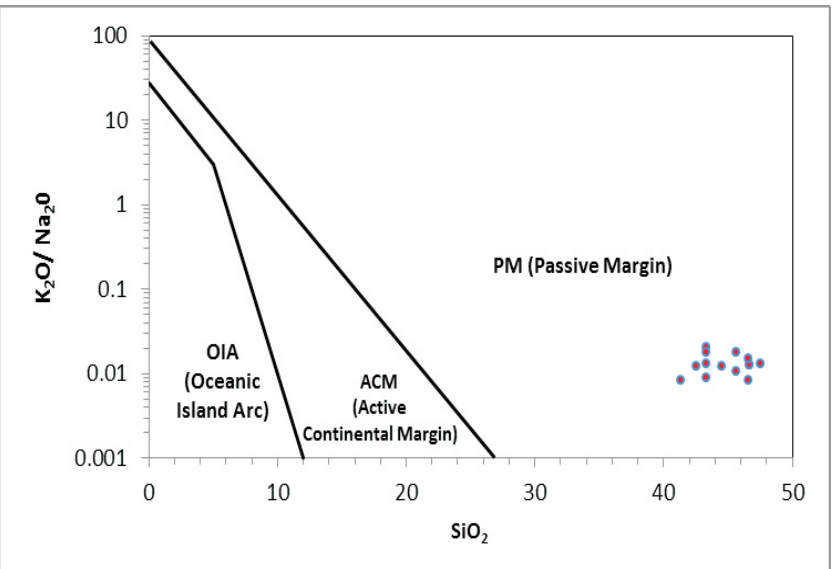

Fig. 14: Tectonic discrimination plot (after Roser and Korsch, 1986).

$A_{\text {sN }}$

P-ISSN 2536-6904, E-ISSN 2705-2761 African Journal of Science \& Nature Vol. 10, 102-113 (2020) 
The chemical index of alteration (CIA) ranges from 45.16-52.26\% while the chemical index of weathering (CIW) ranges between 45.20 and $52.30 \%$; both indicating weak to moderate degree of chemical decomposition and weathering of the source materials respectively. The dot and line plot for CIA and CIW is shown in figures 14 and 15 in that order.

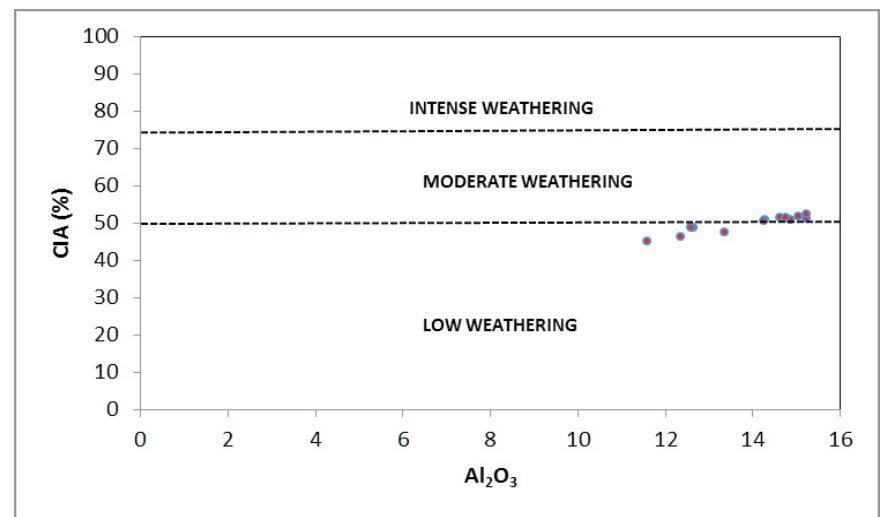

Fig 14: Dot plot of CIA against $\mathrm{Al}_{2} \mathrm{O}_{3}$ of Ikpeshi Marble

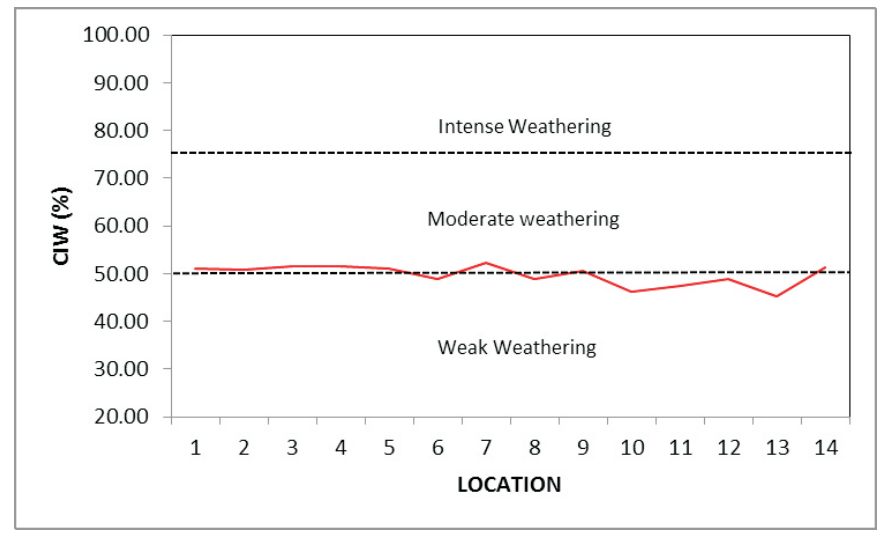

Fig. 15: Line plot of CIW of Ikpeshi Marble

Furthermore, the leaching of the highly mobile elements during active chemical weathering depleted $\mathrm{Na}$ and $\mathrm{K}$ contents in the samples but conversely enhanced the partial transformation of the source rock to clay minerals. A plot of $\mathrm{K}_{2} \mathrm{O}$ agains $\mathrm{Al}_{2} \mathrm{O}$ in figure 17a below depicts more clearly the preponderance of illite in the impure marble samples -a consequence of chemical susceptibility of source area.



Fig. 17a: Plot of $\mathrm{K}_{2} \mathrm{O}$ against $\mathrm{Al}_{2} \mathrm{O}_{3}$

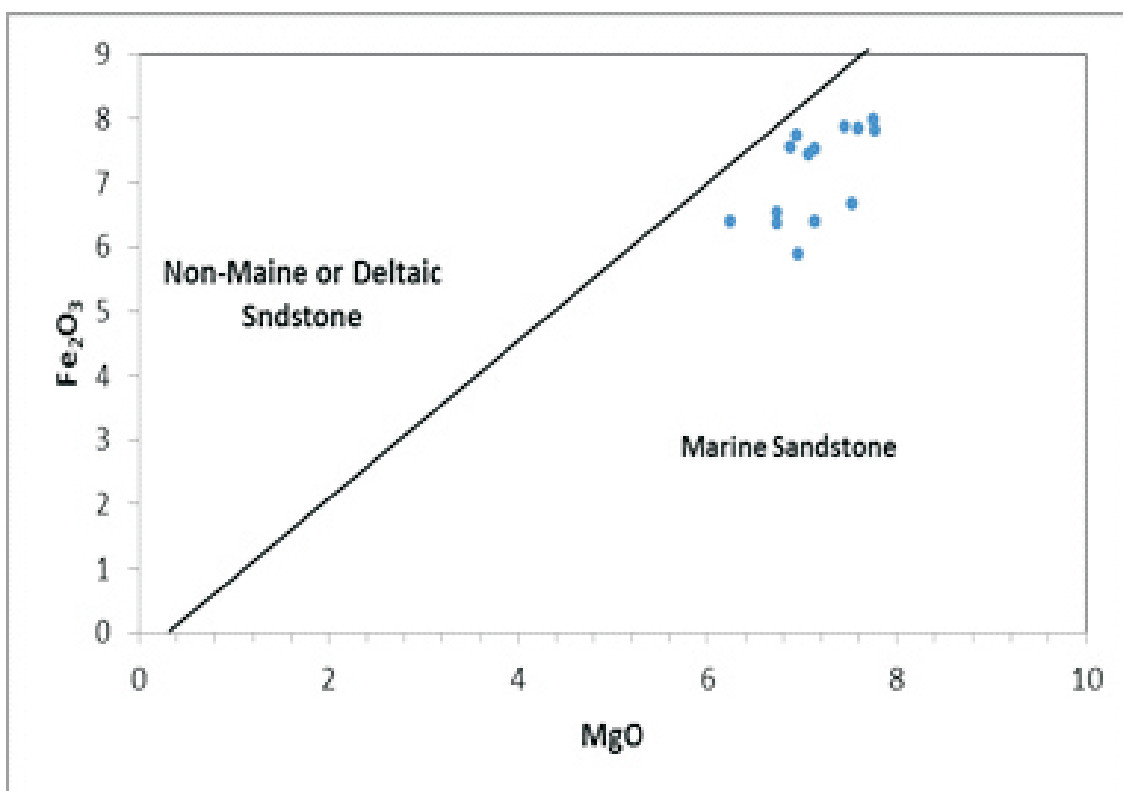

Fig. 17b: Plot of $\mathrm{Fe}_{2} \mathrm{O}_{3}$ versus $\mathrm{MgO}$ for Environment of Deposition

The plot of the $\mathrm{Fe}_{2} \mathrm{O}_{3}$ against $\mathrm{MgO}$ predicts a marginal marine depositional environment for the marble protolith as shown in figure $17 \mathrm{~b}$ above.

\section{DESCRIPTIVE STATISTIC OFTHE ANALYSED RESULT}

Analyzed statistical parameters aremean, median, standarddeviation, variance andrange. The mean value of $\mathrm{SiO}$ $\mathrm{Al}_{2} \mathrm{O}_{3}, \mathrm{CaO}, \mathrm{Fe}_{2} \mathrm{O}_{3}, \mathrm{MgO}, \mathrm{Na}_{2} \mathrm{O}, \mathrm{MnO}, \mathrm{K}_{2} \mathrm{O}$ andP $\mathrm{O}_{5}$ are $44.80,13.81,12.35,9.46,8.87,1.59,1.13,0.75,0.03$, and 0.02 respectively. Table 1 shows the descriptive statistic of the analyzed oxides.

Table 1: Descriptive Statistics of Analyzed oxides*M_Mean *MD_Median *SD_Standard Deviation *Var_Variance *R_Range *Min_Minimum *Max_Maximum

Table 1: Descriptive Statistics of Analyzed oxides*M_Mean *MD_Median *SD_Standard Deviation *Var_Variance *R_Range *Min_Minimum *Max_Maximu m

\begin{tabular}{lrrrrrrrr} 
0xidles & M & MD & S.D & Var. & R & Min. & Max. & Sum \\
\hline $\mathrm{Si0}_{2}$ & 44.8 & 45.1 & 1.91 & 3.65 & 6.19 & 41.4 & 47.6 & 627 \\
$\mathrm{Al}_{2} \mathbf{0}_{3}$ & 13.8 & 14.3 & 1.25 & 1.56 & 3.65 & 11.6 & 15.2 & 193 \\
$\mathrm{Ti0}_{2}$ & 0.75 & 0.75 & 0.08 & 0.01 & 0.24 & 0.64 & 0.88 & 10.5 \\
$\mathrm{Fe}_{2} \mathbf{0}_{3}$ & 9.46 & 9.91 & 0.96 & 0.92 & 2.76 & 7.79 & 10.6 & 132 \\
$\mathrm{Mn}_{0} 0$ & 1.13 & 0.14 & 3.7 & 13.7 & 13.9 & 0.12 & 14 & 15.8 \\
$\mathrm{Ca}_{0}$ & 12.4 & 12.4 & 0.45 & 0.2 & 1.59 & 11.7 & 13.3 & 173 \\
$\mathrm{Mg}_{0}$ & 8.87 & 8.82 & 0.55 & 0.3 & 1.9 & 7.75 & 9.65 & 124 \\
$\mathrm{~K}_{2} \mathbf{0}$ & 0.02 & 0.02 & 0.01 & 0 & 0.02 & 0.01 & 0.03 & 0.29 \\
$\mathrm{Na}_{2} \mathbf{0}$ & 1.59 & 1.56 & 0.11 & 0.01 & 0.31 & 1.44 & 1.75 & 22.2 \\
$\mathbf{P}_{2} \mathbf{0}_{5}$ & 0.03 & 0.03 & 0.01 & 0 & 0.04 & 0.01 & 0.05 & 0.4 \\
\hline
\end{tabular}

JSN P-ISSN 2536-6904, E-ISSN 2705-2761 African Journal of Science \& Nature Vol. 10, 102-113 (2020) 
Correlation was incorporated into the analysis to highlight the relationship among metals, and similarities in their geochemical behavior. The analysis revealed a wide range of variation in the correlation values as both positive and negative correlation was established between some compounds. The different range of correlation and

its indication is shown in Table 2. Strong correlation between two oxides assertively suggests the derivation of materials from same correlation on the contrary is indicative of derivation of heterogeneous source or derivation from different source area

\section{Table 2: Pearson correlation of the major oxides analyzed}

$\begin{array}{lllllllll}\text { OxidesS }_{10} & \mathrm{Al}_{2} \mathrm{O}_{3} & \mathrm{TiO}_{2} & \mathrm{Fe}_{2} \mathrm{O}_{3} \mathrm{MnO} & \mathrm{CaO} & \mathrm{MgO} & \mathrm{K}_{2} \mathrm{O} & \mathrm{Na}_{2} \mathrm{O} & \mathrm{P}_{2} \mathrm{O}_{5}\end{array}$

$\mathrm{SiO}_{2} \quad 1$

$\mathrm{Al}_{2} \mathrm{O}_{3} \quad 0.36 \quad 1$

$\mathrm{Ti}_{2} \quad 0.49 \quad 0.76 \quad 1$

$\mathrm{Fe}_{2} \mathrm{O}_{3} \quad 0.31 \quad 0.72 \quad 0.65$

$\begin{array}{lllll}\mathrm{MnO} & 0.26 & 0.22 & 0.36 & 0.27\end{array}$

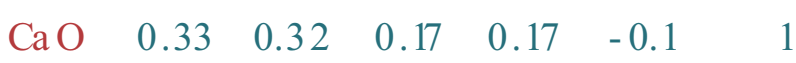

$\begin{array}{llllllll}\mathrm{MgO} & 0.56 & 0.59 & 0.71 & 0.61 & 0.41 & 0.36 & 1\end{array}$

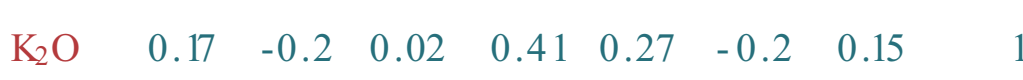

$\begin{array}{llllllllll}\mathrm{Na}_{2} \mathrm{O} & 0.68 & 0.21 & 0.39 & 0.36 & 0.45 & 0.46 & 0.56 & 0.14 & 1\end{array}$

$\begin{array}{llllllllll}\mathrm{P}_{2} 0_{5} & 0.15 & -0.2 & -0.1 & -0.2 & 0.04 & 0.18 & -0.3 & 0.2 & 0.16\end{array}$

Figure 18 is a correlation plot of $\mathrm{TiO}_{2}$ and $\mathrm{Al}_{2} \mathrm{O}_{3}$ with a correlation coefficient of 0.5762 .

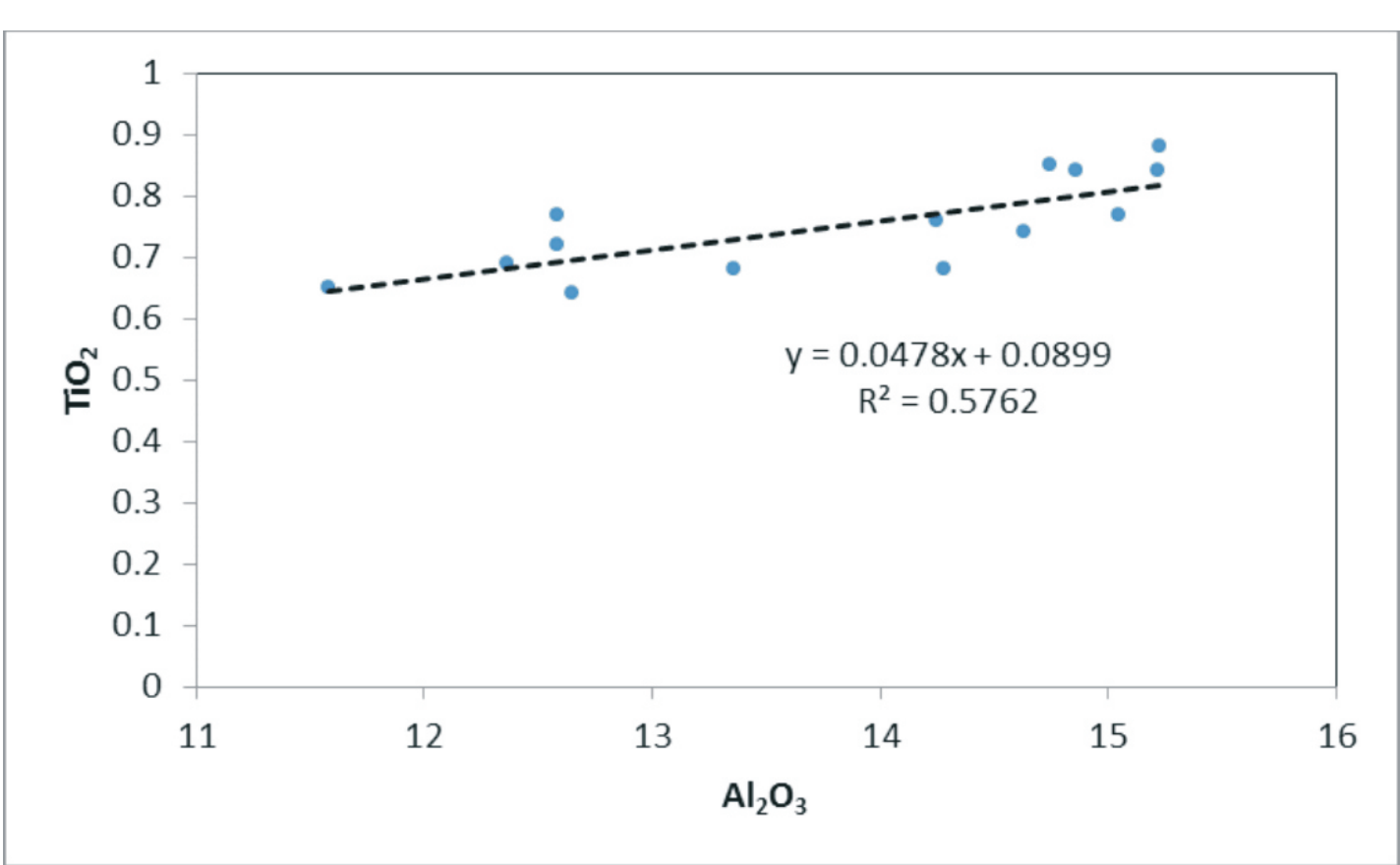

Fig. 18: Correlation plot of $\mathrm{TiO}_{2}$ against $\mathrm{Al}_{2} \mathrm{O}_{3}$

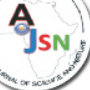

P-ISSN 2536-6904, E-ISSN 2705-2761

\section{Component Matrix Analysis}

Table 3 shows Varimax rotated factor matrix of the linearly uncorrelated components of the fourteen marble samples in the study area Component 1,2 and 3 accounts for $13.13 \%, 16.13 \%, 14.46 \%$ of vaiance, and $40.8 \%$

\section{Table 3: Varimax rotated fact or matrix of the linearly uncorrelated components}

\begin{tabular}{|c|c|c|c|c|c|}
\hline \multirow[t]{2}{*}{ Oxides } & \multicolumn{2}{|c|}{ Component } & \multicolumn{3}{|c|}{ Percentage } \\
\hline & 1 & 2 & 3 & $\%$ & Cum. \\
\hline $\mathrm{SiO}_{2}$ & 0.71 & 0.36 & 0.2 & 40.83 & 40.83 \\
\hline $\mathrm{Al}_{2} \mathbf{O}_{3}$ & 0.75 & -0.49 & 0.12 & 16.13 & 56.96 \\
\hline $\mathrm{Ti}_{2}$ & 0.84 & -0.25 & -0.07 & 14.46 & 71.41 \\
\hline $\mathrm{Fe}_{2} \mathrm{O}_{3}$ & 0.77 & -0.2 & -0.33 & 8.7 & 80.12 \\
\hline MnO & 0.5 & 0.28 & -0.43 & 7.43 & 87.54 \\
\hline $\mathrm{CaO}$ & 0.41 & 0.13 & 0.74 & 5.44 & 92.99 \\
\hline $\mathrm{MgO}$ & 0.88 & -0.1 & -0.03 & 3.06 & 96.05 \\
\hline $\mathrm{K}_{2} \mathrm{O}$ & 0.19 & 0.53 & -0.66 & 2.46 & 98.51 \\
\hline $\mathrm{Na}_{2} \mathrm{O}$ & 0.7 & 0.47 & 0.22 & 1.35 & 99.86 \\
\hline $\mathbf{P}_{2} \mathbf{0}_{5}$ & -0.08 & 0.73 & 0.24 & 0.14 & 100 \\
\hline $\operatorname{vat}$ & & & 14.46 & & \\
\hline
\end{tabular}

\section{CONCLUSION}

The XRF and stable isotope analyses of the fourteen marble samples obtained from the study area clearly revealed the predominance of $\mathrm{SiO}_{2}(41.36-47.55), \mathrm{Al}_{2} \mathrm{O}$ (12.36 -15.23), $\mathrm{TiO}_{2}(0.64-0.88), \mathrm{Fe}_{2} \mathrm{O}_{3}(7.79-10.55)$, $\mathrm{MnO}(0.12-0.15), \mathrm{CaO}(11.66-13.25), \mathrm{MgO}(7.75-9.65)$, $\mathrm{K}_{2} \mathrm{O}(0.012-0.3), \mathrm{Na}_{2} \mathrm{O}(1.44-1.75)$ and $\mathrm{P}_{2} \mathrm{O}_{5}(0.01-0.05)$. All the sampled marble are almost entirely dolomitic, with a relative percentage range of $-5 \%-4 \%$ for $\mathrm{CaO}$ and $93 \%$ $103 \%$ for $\mathrm{MgO}$. However, comparison of these samples with other known marble environments a bruptly signifiesa rather lower $\mathrm{CaO}$ and $\mathrm{MgO}$ content but with high $\mathrm{SiO}_{2}$ anomaly.All the marble sample falls within the calc-silicate group and are poorly dolonitic. Bivariate plot $\mathrm{K}_{2} \mathrm{O}$ agans $\mathrm{Na}_{2} \mathrm{O}$, a rook, 1974) disparately indicates 'quartz poor' and 'quartz

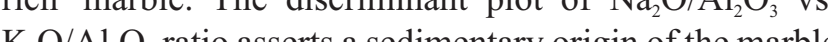
$\mathrm{K}_{2} \mathrm{O}_{2} \mathrm{Al}_{2} \mathrm{O}_{3}$ atio asserts a sedino (limestone) protolith. From the bivariate tectonic discrinination deduced that the protolith was precipitated along a passive between 45.16 and $52.26 \% \cdot 45$ and $52.30 \%$; indicating wekk to modere degree of weatheringand altration Plot of $\mathrm{Fe}_{2} \mathrm{O}$ vs. $\mathrm{MgO}$ predicts a marginal marine depositional enviro betronental of the protolth. Strong correlation exists $\mathrm{Ce}_{2} \mathrm{O}_{3}(0.72), \mathrm{TiO}_{2}-\mathrm{Mg}(0.71) \mathrm{SiO}_{2}-\mathrm{KO}_{2} \mathrm{O}(0.17), \mathrm{SiO}_{2}$ $\mathrm{POO}_{2}(0.15), \mathrm{TiO}_{2}-\mathrm{CaO}(0.17), \mathrm{TiO}_{2}-\mathrm{K}_{2} \mathrm{O}(0.02), \mathrm{Fe}_{2} \mathrm{O}_{3}$
$56.96 \%$ and $71.41 \%$ of the total cumulative percentage of the analyzed samples respectively. Predominant oxides are: $\mathrm{TiO}_{2}, \mathrm{Al}_{2} \mathrm{O}_{3}, \mathrm{MgO}, \mathrm{Fe}_{2} \mathrm{O}_{3}$ and $\mathrm{Na}_{2} \mathrm{O}$ (Component 1 ); $\mathrm{P}_{2} \mathrm{O}_{5}$ and $\mathrm{K}_{2} \mathrm{O}$ (Component 2 ) and $\mathrm{CaO}$ (Component 3 )
$\mathrm{CaO}$ (0.17), $\mathrm{CaO}-\mathrm{P}_{2} \mathrm{O}_{5}(0.18), \mathrm{MgO}-\mathrm{Na}_{2} \mathrm{O}(0.56), \mathrm{K}_{2} \mathrm{O}-$ $\mathrm{Na}_{2} \mathrm{O}, \mathrm{K}_{2} \mathrm{O}-\mathrm{P}_{2} \mathrm{O}_{5}, \mathrm{Na}_{2} \mathrm{O}-\mathrm{P}_{2} \mathrm{O}_{5}(0.16)$ very weak correlation exists, symptomatic of derivation from diverse source area. XRF and stable isotope analytical results of the study conclusively deduced a poor quality marble with high silica impurity, derived from a hybrid sedimentary protolith precipitated under a tropical humid condition within a shallow marine environment along a passive continental margin

\section{REFERENCES}

Alabi A. B., Olatunji S., Babalola O. A., Nwankwo L. I, Johnson L. M., Odutayo J. O. \& Alabi A. (2013): Structural and qualitative analysis of solid minerals (marble) in selected locations in Nigeria, Nigerian Journal of Physics 24:68-76. Boynton, S.(1980): Chemistry and technology of Sons Inc. New York, 300

Carr, D. D. \& Rooney, L.F. (1983): Limestone and dolomite. In: Lefond, S. Y. (Ed.) Industria minerals and rocks (5th edition). New York: America Inst. Met. And Petr. Engr. Inc; 833- 868.

Clarke, F. N. (1924): The Data of Geochemistry (2nd ed.) Washington Government Printing Office; 782.

Crook K.A.W. (1974).Lithogenesis and geotectonics: The significance of compositional variation in flysch arenites (greywackes). Soc. of Eco. Paleo. \&

Goldschmidth, J R. Graff L. \& Joensu, O I. (1955):The occurrence of magnesium calcite in nature. 
Geochim Cosmochim in Acta, 1: 212-230.

Grant, W. F, Papertzian, V. C.\& Kingston, P. W. (1989): Geochemistry of Grenville marble in southeastern Ontario; Ontario Geological Southeastern Ontario; Ontario Geologic
Survey, Mineral Deposit Circular 28: 266.

Roser, B. P. \& Korsch, R. J.(1986): Determination of ectonic setting of sandstone-mudstone suites using $\mathrm{SiO}_{2}$ content and $\mathrm{K}_{2} \mathrm{O} / \mathrm{Na}_{2} \mathrm{O}$ ratio. $J$. Geol.
94: 635-650.

Scott, P. W.\& Dunham, A. C. (1984): Problems in the evaluation of limestone for divers market. $6^{\text {"I }}$ Indian MIN. Intl Congress, Toronto, 1-21.

Storey, C.C. \& Vos, M.A. (1988): Industrial Minerals of the Pembroke-Renfrew Area, Part 1: Marble; Ontario Geological Survey, Mineral Deposits Circular 21: 132 . 